\title{
UPAYA MENINGKATKAN KREATIFITAS BELAJAR MAHASISWA PENDIDIKAN MATEMATIKA MENGGUNAKAN GEOGEBRA DENGAN PENDEKATAN PROBLEM POSING
}

\author{
Syariful Fahmi \\ Program Studi Pendidikan Matematika FKIP UAD \\ Jl. Prof. Dr. Soepomo, SH. Janturan Yogyakarta \\ syarifulfahmi@gmail.com \\ Soffi Widyanesti Priwantoro \\ Program Studi Pendidikan Matematika FKIP UAD \\ Jl. Prof. Dr. Soepomo, SH. Janturan Yogyakarta
}

\begin{abstract}
Problems in learning introductory computer science which need urgent resolution is the problem related to the creativity of the student learning. Along with the existence of the use of software geogebra to ease the learning of mathematics, as well as the existence of a problem posing approach, the above problem resolution efforts got the right momentum. The learning approach that is used in this research is the $h$ problem posing approach with combined use of software geogebra. As for the purposes of this learning approach is to improve creativity of students learning.This research activity involves two lecturers and 21 students in class introduction of computer science at semester 4 academic year 2015-2016. Student creativity data collected by using a sheet of observation which further analyzed in qualitative descriptive.Based on the results of data analysis it is known that the use of the problem posing approach can raise average student learning where creativity before the cycle 1 is being implemented (score 1.06). While once held a series of activities cycle 2 is known to the average student learning categories include creativity high (score 2.09). This indicates the occurrence of increased creativity learning of students.
\end{abstract}

Keywords: creativity of the student learning, geogebra, problem posing approach

\begin{abstract}
ABSTRAK. Permasalahan dalam pembelajaran pengantar ilmu komputer yang membutuhkan penyelesaian yang mendesak adalah permasalahan yang berkaitan dengan kreatifitas belajar mahasiswa. Seiring dengan adanya penggunaan software geogebra untuk mempermudah pembelajaran matematika, serta adanya pendekatan problem posing, upaya penyelesaian masalah di atas mendapat momentum yang tepat. Pendekatan pembelajaranyang digunakan dalam penelitian ini adalah pendekatan problem posing dengan dipadukan penggunaan software geogebra. Adapun tujuan digunakannnya pendekatan pembelajaran ini adalah untuk meningkatkan kreatifitas belajar mahasiswa. Kegiatan penelitian ini melibatkan 2 (dua) dosen dan 21 mahasiswa di kelas unggulan mata kuliah pengantar ilmu komputer pada semester 4 tahun akademik 2015-2016. Data kreatifitas mahasiswa dikumpulkan dengan menggunakanlembar observasi yang selanjutnya dianalisis secara deskriptif kualitatif. Berdasarkan hasil analisis data diketahui bahwa penggunaan pendekatan problem posing dapat meningkatkan rata-rata kreatifitas belajar mahasiswa dimana sebelum dilaksanakan siklus 1 adalah sedang (skor 1.06) dan setelah dilaksanakan rangkaian kegiatan siklus 2 diketahui rata-rata kreatifitas belajar
\end{abstract}


mahasiswa termasuk kategori tinggi (skor 2.09). Hal ini menandakan terjadinya peningkatan kreatifitas belajar mahasiswa.

Kata kunci: kreatifitas belajar, geogebra, pendekatan problem posing

\section{PENDAHULUAN}

Belajar sebagai proses dipengaruhi oleh banyak faktor. Faktor tersebut mencakup dua hal yakni faktor yang berasal dalam diri mahasiswa dan faktor yang berasal dari luar mahasiswa. Faktor yang berasal dari luar mahasiswa meliputi: (1) faktor non sosial seperti keadaan udara, suhu udara, cuaca, waktu dan lain sebagainya, (2) faktor sosial yaitu faktor manusia baik itu manusia hadir secara langsung maupun tidak langsung. Faktor dari dalam diri mahasiswa sendiri yaitu: (1) fisiologis yaitu kondisi jasmani pada umumnya dan (2) faktor psikologis yang meliputi motivasi, minat, sikap dan lain sebagainya (Sumadi Suryabrata, 1995:249).

Salah satu tugas utama dosen adalah mengajar. Dosen dituntut menguasai strategi-strategi atau pendekatan-pendekatan dalam pembelajaran. Dosen diharapkan dapat menyampaikan materi pelajaran kepada mahasiswa secara mudah dengan memperhatikan kecenderungan dan kebutuhan mahasiswa secara umum melaui penguasaan strategi atau pendekatan pembelajaran tersebut.

Pendekatan problem posing merupakan salah satu pendekatan pembelajaran yang mendorong mahasiswa untuk membentuk soal sendiri dan kemudian meyelesaikan soal tersebut. Dengan metode ini mahasiswa dihadapkan kepada situasi dimana ia diberi kebebasan secara aktif untuk membentuk soal dan menyelesaikan soal.

Sejauh pengetahuan penulis, selama ini belum ada penelitian yang menggunakan pendekatan tersebut untuk mewujudkan kreatifitas dalam pembelajaran matematika, khususnya di Pendidikan Matematika UAD, terlebih pada mata kuliah Pengantar Ilmu Komputer. Jadi, menurut hemat penulis, masalah tersebut layak untuk diteliti.

Dari uraian di atas dapat dirumuskan masalah sebagai berikut:

1) Bagaimanakah pembelajaran Pengantar Ilmu Komputer pada mahasiswa pendidikan matematika Universitas Ahmad Dahlan melalui pendekatan problem posing?

2) Apakah pendekatan problem posing dapat mewujudkan pembelajaran matematika yang kreatif?

Tujuan penelitian ini adalah:

1) Mengungkap pembelajaran Pengantar Ilmu Komputer pada mahasiswa pendidikan matematika Universitas Ahmad Dahlan melalui pendekatan problem posing. 
2) Mewujudkan pembelajaran matematika yang kreatif.

\section{METODE PENELITIAN}

Jenis penelitian ini adalah Penelitan Tindakan Kelas (PTK) atau Classroom Action Research (CAR) model Kemmis dan Taggart yang terdiri dari empat tahapan, yakni Planning, Acting, Observing, and Reflecting.

Penelitian tindakan kelas ini mengambil bentuk penelitian kolaborasi, yakni mahasiswa bekerjasama dengan dosen mata pelajaran matematika tergabung dalam satu tim untuk melakukan penelitian dengan tujuan untuk menjawab permasalahan di kelas dan untuk memperbaiki praktek-praktek dalam pembelajaran. Hubungan anggota dalam tim kolaborasi adalah bersifat kemitraan, sehingga kedudukan peneliti dan dosen adalah sama untuk berusaha memacahkan permasalahan yang ada di dalam kelas. Secara umum, peneliti dituntut untuk terlibat secara langsung dalam penelitian tindakan kelas ini.

Pendekatan yang digunakan dalam penelitian ini adalah pendekatan penelitian kualitatif yakni prosedur penelitian yang menghasilkan data deskriptif berupa kata-kata tertulis atau lisan dari orang-orang tentang perilaku yang dapat diamati. Penelitian ini dilaksanakan di mata kuliah Pengantar Ilmu Komputer pada mahasiswa semester 4 Pendidikan Matematika UAD.

Instrumen yang digunakan dalam penelitian ini adalah:

1) Lembar Kerja mahasiswa (LKM).

2) Lembar observasi.

3) Dokumentasi berupa foto/gambar.

4) Angket.

5) Latihan soal.

Pada tahap action (tindakan), mulailah diterapkan langkah-langkah pembelajaran yang telah direncanakan semula. Langkah-langkah tersebut yakni (adopsi dari Budiasih dan Kartini dalam Budi Hartati): dosen membuka kegiatan pembelajaran, menyampaikan tujuan pembelajaran, menjelaskan secara singkat materi pelajaran, memberikan contoh soal, memberikan kesempatan kepada mahasiswa untuk bertanya tentang hal-hal yang belum jelas, memberikan kesempatan kepada mahasiswa untuk membentuk soal dan menyelesaikannya, mengarahkan mahasiswa untuk membuat kesimpulan, membuat 
rangkuman berdasarkan kesimpulan yang dibuat mahasiswa, serta menutup kegiatan pembelajaran

Pada tahap observing (pengamatan), kegiatan pembelajaran di kelas dicatat atau direkam, dan didokumentasikan.Kegiatan tersebut tidak hanya yang dilakukan oleh mahasiswa, tetapi juga yang dikerjakan oleh dosen/mitra. Pada tahap reflecting (refleksi), dilakukan pengungkapan kembali apa yang telah dilaksanakan. Penilaian dilakukan, apakah rencana yang telah disusun dapat terlaksana dengan baik atau tidak.

\section{HASIL DAN PEMBAHASAN}

\subsection{Hasil}

Kegiatan pembelajaran terdiri atas dua periode atau siklus. Pada siklus pertama dan kedua terlaksana dua pertemuan. Setiap tindakan memiliki metode atau cara pembelajaran yang berbeda tetapi masih menggunakan pendekatan problem posing, dan pada setiap tindakan memiliki tujuan pembelajaran yang sama yaitu peningkatan pembelajaran matematika yang kreatif. Siklus I menggunakan cara pembelajaran dimana mahasiswa menyusun soal secara individu. Dalam penyusunan soal ini mahasiswa tidak asal menyusun soal, akan tetapi juga mempersiapkan jawaban dari soal yang sedang disusunnya. Dengan kata lain, setelah mahasiswa tersebut dapat membuat soal maka mahasiswa juga dapat menyelesaikan soal tersebut. Tindakan II menggunakan cara pembelajaran dimana mahasiswa menyusun soal dalam kelompok dan kemudian kelompok

yang lain berusaha menjawabnya, dimana soal yang telah dibuat kemudian didistribusikan dengan cara penggeseran kepada temannya.

Setelah melakukan pengumpulan data dengan menggunakan instrumen penelitian terhadap pembelajaran matematika pada materi penggunaan geogebra dalam menyelesaikan masalah dalam geometri transformasi (refleksi, translasi, rotasi, dan dilatasi) dengan menggunakan pendekatan problem posing diperoleh hasil sebagai berikut.

1. Hasil Tindakan Siklus I

a. Perencanaan 
Adapun kegiatan yang telah dilakukan dalam tahap perencanaan ini adalah membuat rencana pembelajaran dengan menggunakan pendekatan problem posing, serta menyiapkan lembar observasi dan lembar kerja mahasiswa (LKM).

b. Pelaksanaan Tindakan

Pada tahap ini dilaksanakan proses pembelajaran sesuai rencana pembelajaran yang telah dibuat.

1) Pertemuan $I$

Pertemuan ini dilaksanakan pada hari Selasa tanggal 14 Juni 2016. Materi pembelajaran tentang menggunakan geogebra untuk materi refleksi. Pada awal pertemuan ini, dosen menjelaskan bahwa pada pembelajaran mulai hari ini memasuki pokok bahasan baru, yakni menggunakan geogebra untuk materi refleksi. Jika sebelumnya dosen menjelaskan kemudian memberikan contoh dan selanjutnya mahasiswa diberi soal untuk dipecahkan, hari ini setelah mendapatkan contoh diharapkan mahasiswa dapat membuat masalah atau soal dan sekaligus mempersiapkan jawabannya. Dosen menjelaskan tentang fungsi fungsi yang digunakan dalam geogebra untuk materi refleksi. Dosen memerintahkan supaya mahasiswa membuat masing-masing contoh dua buah soal yang diselesaikan dengan geogebra. Dosen berkeliling kelas untuk mengecek kesungguhan mahasiswa.

2) Pertemuan II

Pertemuan ke-2 dilaksanakan pada hari Selasa tanggal 21 Juni 2016. Pada pertemuan ini dosen melanjutkan pembelajaran tentang rotasi objek dengan bantuan geogebra. Pada sub bab ini dosen memberikan contoh penggunaan geogebra untuk rotasi.

\section{c. Refleksi}

Dalam merefleksi tindakan yang telah dilakukan pada pertemuan I dan pertemuan II siklus pertama difokuskan pada masalah yang muncul selama pelaksanaan tindakan. Kemudian peneliti bersama dosen mendiskusikannya 
untuk mengevaluasi keberlangsungan tindakan berikutnya. Dari data hasil lembar observasi, angket, dan wawancara tidak terstruktur terungkap masalah kreatifitas mahasiswa dalam dalam membuat soal dan memecahkan soal masih sering bertanya bertanya pada mahasiswa yang lain.

Berdasarkan kondisi dan permasalahan di atas maka perlu dilakukan revisi untuk tindakan selanjutnya, yaitu:

1. Memotivasi mahasiswa untuk terlibat aktif dalam diskusi kelas maupun dalam kerja kelompok, supaya tidak hanya menjadi penonton.

2. Mahasiswa akan diberi kebebasan dalam membuat soal dan memecahkannya bersama dengan teman kelompoknya.

3. Mendorong mahasiswa agar mahasiswa yang sudah paham membantu temannya yang belum paham.

2. Hasil Tindakan siklus II

a. Perencanaan

Kegiatan yang telah dilakukan dalam tahap perencanaan ini adalah membuat rencana pembelajaran dengan menggunakan pendekatan problem posing, serta menyiapkan lembar observasi dan menyiapkan jurnal.

b. Pelaksanaan Tindakan

Pelaksanaan tindakan pada tahap ini dilakukan sesuai rencana pembelajaran yang telah dibuat.

1) Pertemuan III

Pertemuan ini dilaksanakan pada hari Kamis, 23 Juni 2016. Materi pembelajaran yaitu tentang Translasi dengan menggunakan geogebra. Pada pertemuan ini dosen lebih banyak menerangkan tentang fungsi geogebra dalam menyelesaikan soal dan membuat media pembelajaran matematika materi translasi. Kesulitan yang dijumpai mahasiswa saat menggunakan fungsi penulisan latex pada penggunaan logika.

2) Pertemuan IV

Pertemuan ini dilaksanakan pada hari Selasa, 28 Juni 2016. Materi pembelajaran tentang dilatasi serta membuat media sederhana dengan 
geogebra. Pada pertemuan ini mahasiswa perkelompok juga diminta untuk membuat beberapa soal, ataupun memperdalam soal yang telah dibuat pada pertemuan sebelumnya dan meminta kelompok lain untuk memecahkannya.

\section{c. Refleksi}

Hasil observasi, jurnal, dan wawancara tidak terstruktur menunjukkan mahasiswa kesulitan dalam membuat media sederhana dengan geogebra, namun pada akhirnya mereka mampu menghasilkan produk media sederhana dengan geogebra. Berikut adalah salah satu hasil karya mahasiswa:

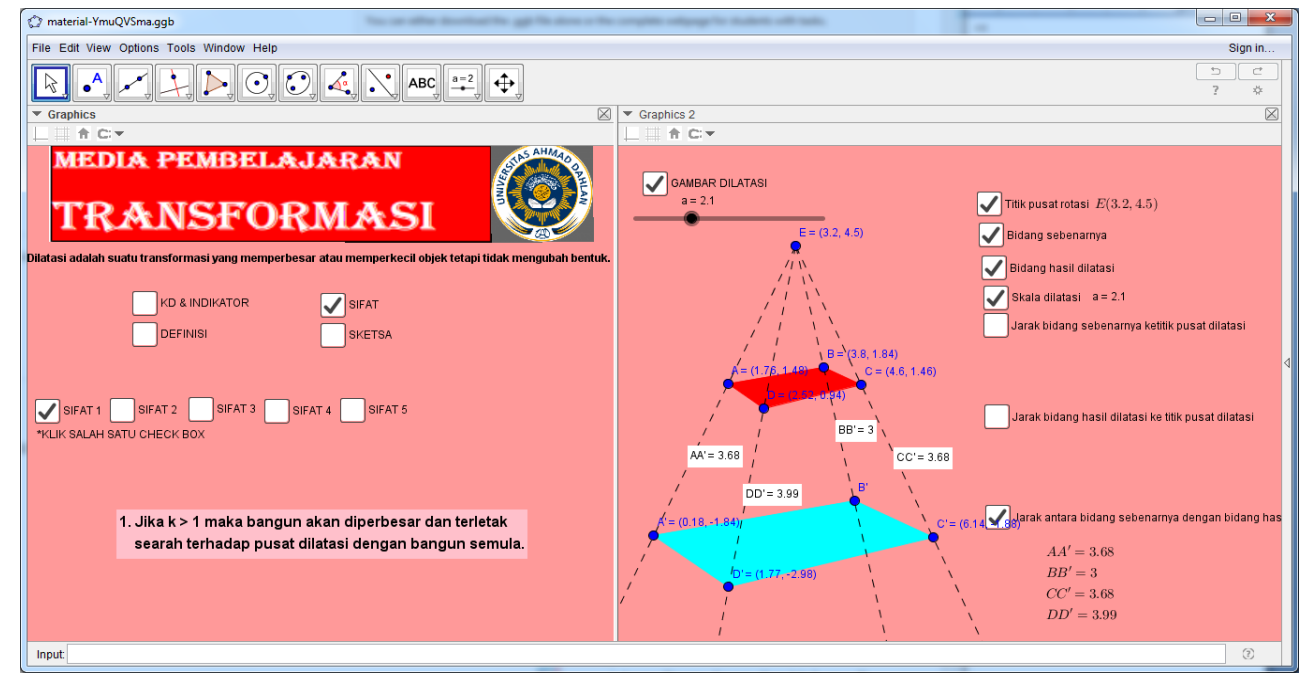

Gambar 1: hasil karya mahasiswa

Anggota peneliti dan seorang dosen mengunakan lembar observasi tentang kreatifitas untuk memantau kegiatan belajar mahasiswa. Data tersebut selanjutnya dianalisis secara deskriptif untuk mengetahui ada tidaknya peningkatan kreatifitas belajar mahasiswa. Hasil dari analisis deskriptif tentang kreatifitas belajar mahasiswa ditunjukkan pada tabel berikut ini. 
Tabel 1.Persentase skor kreatifitas belajar mahasiswa

\begin{tabular}{|c|c|c|c|c|c|c|c|c|c|}
\hline \multirow{3}{*}{ No } & \multirow{3}{*}{ Indikator kreatifitas } & \multicolumn{8}{|c|}{ Persentase mahasiswa $(\%)$} \\
\hline & & \multicolumn{4}{|c|}{ Siklus 1} & \multicolumn{4}{|c|}{ Siklus 2} \\
\hline & & $\mathbf{0}$ & 1 & 2 & 3 & $\mathbf{0}$ & 1 & 2 & 3 \\
\hline 1. & $\begin{array}{l}\text { Memberikan gagasan atau } \\
\text { usulan terhadap suatu } \\
\text { masalah }\end{array}$ & 38.10 & 42.86 & 9.52 & 9.52 & 19.05 & 23.81 & 33.33 & 23.81 \\
\hline 2. & $\begin{array}{l}\text { Menanggapi pendapat } \\
\text { teman }\end{array}$ & 33.33 & 38.10 & 19.05 & 9.52 & 9.52 & 19.05 & 28.57 & 42.86 \\
\hline 3. & Mengajukan pertanyaan & 38.10 & 33.33 & 19.05 & 9.52 & 9.52 & 19.056 & 33.33 & 38.10 \\
\hline 4. & $\begin{array}{l}\text { Mahasiswa } \\
\text { merancang/membuat alat } \\
\text { peraga/alat bantu untuk } \\
\text { menyelesaikan masalah }\end{array}$ & 19.05 & 42.85 & 23.81 & 14.29 & 9.52 & 14.29 & 33.33 & 42.86 \\
\hline 5. & $\begin{array}{l}\text { Mahasiswa } \\
\text { membuat/mencari soal } \\
\text { sendiri untuk dipecahkan }\end{array}$ & 47.62 & 28.57 & 14.29 & 9.52 & 9.52 & 14.29 & 33.33 & 42.86 \\
\hline 6. & $\begin{array}{l}\text { Lancar dalam } \\
\text { mengemukakan ide secara } \\
\text { lisan dan tulisan }\end{array}$ & 38.09 & 14.29 & 33.33 & 14.29 & 0 & 0 & 33.33 & 66.67 \\
\hline
\end{tabular}

\section{Keterangan:}

Skor 0 berarti sama sekali tidak ada aktifitas seperti yang tertulis dalam indikator.

Skor 1 berarti ada sedikit aktifitas namun belum bermakna.

Skor 2 berarti melakukan beberapa aktifitas yang bermakna.

Skor 3 berarti melakukan banyak aktifitas yang bermakna.

Data di atas selanjutnya dianalisis untuk diketahui rata-rata skor kreatifitas belajar mahasiswa. Rata-rata skor kreatifitas belajar ini selanjutnya digunakan untuk mengetahui tingkat kreatifitas belajar dengan menggunakan kriteria atau kategori sebagai berikut:

Tabel 2.Kriteria tingkat kreatifitas belajar

\begin{tabular}{|c|c|}
\hline Skor rata-rata kreatifitas belajar & Tingkat kreatifitas belajar \\
\hline $0,00-0,99$ & Rendah \\
\hline $1,00-1,99$ & Cukup \\
\hline $2,00-3,00$ & Tinggi \\
\hline
\end{tabular}


Berikut tabel skor rata-rata tingkat kreatifitas belajar yang dihasilkan :

Tabel 3.Rata-rata dari skor tiap indikator kreatifitas belajar mahasiswa

\begin{tabular}{|c|l|c|c|c|}
\hline No & Indikator kreatifitas belajar & Siklus 1 & Siklus 2 & Skor Peningkatan \\
\hline 1 & $\begin{array}{l}\text { Memberikan gagasan atau usulan terhadap } \\
\text { suatu masalah }\end{array}$ & 0.9046 & 1.619 & 0.7144 \\
\hline 2 & Menanggapi pendapat teman & 1.0476 & 2.0477 & 1.0001 \\
\hline 3 & Mengajukan pertanyaan & 0.9999 & 2.00016 & 1.00026 \\
\hline 4 & $\begin{array}{l}\text { Mahasiswa merancang/membuat alat } \\
\text { peraga/alat bantu untuk menyelesaikan } \\
\text { masalah }\end{array}$ & 1.3334 & 2.0953 & 0.7619 \\
\hline 5 & $\begin{array}{l}\text { Mahasiswa membuat/mencari soal sendiri } \\
\text { untuk dipecahkan }\end{array}$ & 0.8571 & 2.0953 & 1.2382 \\
\hline 6 & $\begin{array}{l}\text { Lancar dalam mengemukakan ide secara } \\
\text { lisan dan tulisan }\end{array}$ & 1.2382 & 2.6667 & 1.4285 \\
\hline & Rata-rata & 1.06 & 2.09 & 1.02 \\
\hline
\end{tabular}

Dari tabel diatas dapat diketahui bahwa rata-rata kreatifitas belajar mahasiswa sebelum dilaksanakan siklus 1 adalah sedang.dan pada siklus 2 diketahui ratarata kreatifitas belajar mahasiswa termasuk kategori tinggi. Hal ini menandakan terjadinya peningkatan kreatifitas belajar mahasiswa.

\subsection{Pembahasan}

Peningkatan yang terjadi pada kreatifitas belajar mahasiswa ditunjukkan dengan meningkatnya skor pada tiap indikator kreatifitas belajar.Indikator kreatifitas belajar yang memiliki skor peningkatan terbesar adalah indikator ke-6 yakni rasa ingin tahu mahasiswa. Sedangkan indikator yang memiliki skor peningkatan paling kecil adalah indikator ke-4 yakni mahasiswa merancang/membuat alat peraga/alat bantu untuk menyelesaikan masalah. Indikator ke-6 memiliki kaitan erat dengan kedisiplinan waktu dalam menyelesaikan tugas. Hal ini juga merupakan karakter penting yang hendak 
dibangun melalui dunia pendidikan, dimana karakter ini tidak hanya penting dalam konteks belajar di sekolah tetapi juga dalam kehidupan sehari-hari.

Kaitannya dengan indikator ke-4, banyak mahasiswa yang masih mengalami kesulitan untuk mengubah kebiasaan salah dalam kerja kelompok dalam mengerjakan tugas kelompok. Hal yang paling sering dilakukan adalah: jika dimisalkan sebuah kelompok terdiri dari 3 orang diminta menyelesaikan 8 soal matematika, maka kebanyakan mereka menyelesaikannya dengan cara tiap anggota menyelesaikan 2 soal yang menjadi bagiannya saja. Setelah masingmasing menyelesaikan bagiannya selanjutnya baru digabung menjadi satu. Sehingga yang terjadi mayoritas mahasiswa hanya menguasai tugas yang menjadi bagiannya saja. Kebiasaan ini masih perlu upaya lanjutan untuk diperbaiki. Mahasiswa memiliki kecenderungan untuk enggan atau tidak merasa perlu untuk melakukan kerjasama antar kelompoknya. Kebiasaan enggan bekerjasama dengan orang di luar kelompoknya dipicu oleh dorongan berkompetisi antar kelompok yang memang menjadi salah satu bagian pembelajaran yang diharapkan dapat mendorong motivasi belajar. Namun, kompetisi antar kelompok yang dibangun hendaknya tidak sampai menutup ruang kerjasama antar kelompok sehingga mahasiswa tidak terjerumus pada pandangan sempit yang dimiliki kelompoknya saja tanpa mempedulikan pandangan atau ide dari kelompok lain. Sebaliknya, perlu ditumbuhkembangkan pada mahasiswa kebiasaan berbagi ide, gagasan atau solusi dalam menyelesaikan masalah antar kelompok sehingga tercipta ide, gagasan, atau solusi yang lebih komprehensif. Dan dunia pendidikan memiliki kreatifitas untuk membangun kebiasan tersebut.

Penggunaan pendekatan pembelajaran konvensional (dosen lebih dominan) cenderung mengungkung keterlibatan mahasiswa secara aktif dan kreatif. Penggunaan pendekatan tersebut berdampak pada hasil pembelajaran yang lebih sering tidak efektif dan mahasiswa merasa bosan dengan materi yang dipelajinya.Pendekatan pembelajaran yang mengacu pada keterlibatan mahasiswa dan dosen secara aktif dan kreatif mutlak harus dilaksanakan untuk menungkatkan hasil pembelajaran yang dilakukan. Pembelajaran matematika menggunakan pendekatan problem posing menuntut keterlibatan mahasiswa secara aktif. 
Penggunaan pendekatan problem posing dalam pembelajaran matematika berhasil menumbuhkan sikap kreatif dari mahasiswa dalam membuat soal, baik melalui modifikasi dari soal yang sudah ada maupun soal murni yang berasal dari benak mahasiswa.

\section{Kesimpulan dan Saran}

Kesimpulan penerapan model pembelajaran problem posing pada mata kuliah pengantar ilmu komputer tahun akademik 2015-2016 adalah dapat:

1. Meningkatkan kreatifitas belajar mahasiswa semester 4 kelas Unggulan sejumlah 21 mahasiswa.

2. Tingkat kreatifitas belajar dalam siklus 1 adalah sedang, setelah siklus 2 meningkat pada kriteria tinggi.

3. Peningkatan yang terjadi pada kreatifitas belajar bermanfaat dalam membentuk karakter mahasiswa yang berguna dalam kehidupan sehari-hari.

Adapun saran yang dapat diberikan adalah :

1. Perlu diperhatikan tentang keheterogenan anggota kelompok dalam penyususnan anggota kelompok sehingga tidak terjadi ketidakseimbangan antar kelompok yang satu dengan yang lain di dalam kelas.

2. Dalam proses pembelajaran, variasi dalam pembelajaran baik itu media dan sumber yang digunakan, pengelolaan kelas serta bentuk soal perlu ditambah.

\section{DAFTAR PUSTAKA}

Hartati, B., Meningkatkan Kemampuan Mahasiswa dalam Menyelesaikan soal Matematika Melalui Pendekatan Problem Posing di SD Muhammadiyah Tegalrejo, Skripsi UNY, Yogyakarta, 2005.

Zahara, D. T., Kontribusi Strategi Pembelajaran Terhadap Hasil Belajar, Balitbang Depdiknas, Jakarta, 2001.

Darnati, E. T., Upaya Peningkatan Aktifitas Belajar Melalui Pendekatan Problem Posing pada Pembelajaran Matematika, Buletin Pelangi Pagi, 4(1) (2001). Moloeng, L. J., Metodologi Penelitian Kualitatif, PT Remaja Rosdakarya, Bandung, 2002. 
Silberman, M., Active Learning: 101 Strategi Pembelajaran Aktif, YAPPENDIS, Yogyakarta, 2005

Musfiqon, Metodologi Penelitian Pendidikan. Prestasi Pustaka, Jakarta, 2016.

Slameto, Belajar dan Faktor-Faktor yang Mempengaruhinya, PT Rineka Cipta, Jakarta, 2003.

Silberman, M., Active Learning: 101 Strategi Pembelajaran Aktif, YAPPENDIS, Yogyakarta, 2002.

Suryabrata, S., Psikologi Pendidikan, PT Raja Grafindo Persada, Jakarta, 1995.

Surapranata, S., Analisis, Validitas, Reliabilitas, dan Interpretasi hasil Tes: Implementasi Kurikulum 2004, PT Remaja Rosdakarya, Bandung, 2005.

Sukayati, Penelitian Tindakan Kelas, Diklat Dosen Pemandu Mata Pelajaran Matematika SD, 5 s.d 20 Agustus 2002, PPPG Matematika Yogyakarta.

Tim Penelitian Tindakan Matematika SLTPN 4 Sarolangun Jambi, Meningkatkan Kemampuan Mahasiswa Menerapkan Konsep Matematika Melalui Pemberian Tugas Problem Posing Secara Berkelompok, Buletin Pelangi Pagi, 5(2) (2002).

Sanjaya, W., Strategi Pembelajaran Berorientasi Standar Proses Pendidikan, Kencana Prenada Media Grup, Jakarta, 2007. 